Available online at GSC Online Press Directory

GSC Biological and Pharmaceutical Sciences

e-ISSN: 2581-3250, CODEN (USA): GBPSC2

Journal homepage: https://www.gsconlinepress.com/journals/gscbps

(RESEARCH ARTICLE)

\title{
Growth parameters, mineral distribution, chlorophyll content, biochemical constituents and non-enzymatic antioxidant compounds of white yam (Dioscorea rotundata (L) var. gana) grown under salinity stress.
}

\author{
Ndouma Mbondjo Cécile 1, ${ }^{*}$, Nouck Alphonse Ervé 2, Titah Margaret Awah ${ }^{3}$, Ndjouondo Gildas Parfait ${ }^{3}$, \\ Ekwel Sondi Serge ${ }^{1}$, Fotso ${ }^{3}$ and Taffouo Victor Desiré ${ }^{1}$ \\ ${ }^{1}$ Department of Botany, Faculty of Science, The University of Douala, P.O. Box 24157, Douala-Cameroon. \\ ${ }^{2}$ Department of Biological Sciences, Faculty of Sciences, The University of Bamenda, P.O. Box 39 Bambili-Cameroon. \\ ${ }^{3}$ Department of Biology, Higher Teacher Training College, The University of Bamenda, P.O. Box 39 Bambili-Cameroon.
}

Publication history: Received on 03 September 2020; revised on 17 September 2020; accepted on 20 September 2020

Article DOI: https://doi.org/10.30574/gscbps.2020.12.3.0286

\begin{abstract}
Soil salinity has a negative impact on crop production over the world. The effect of salt stress on growth, chlorophyll content, mineral distribution, biochemical constituents and non-enzymatic antioxidant compounds of white yam (Dioscorea rotundata (L) var. gana) cultivar regularly consumed in Cameroon were investigated. Plants were subjected to four different levels concentrations of $\mathrm{NaCl}(0,50,100$ and $200 \mathrm{mM})$, with $0 \mathrm{mM} \mathrm{NaCl}$ as a control. The supply of intake doses of $\mathrm{NaCl}$ in the culture medium significantly $(\mathrm{P}<0.001)$ decreased the dry biomass (roots and shoots), growth parameters (number of leaves, noose diameter, leaf area and stem height) and chlorophyll contents from 100 $\mathrm{mM} \mathrm{NaCl}$. Mineral elements $(\mathrm{K}, \mathrm{Ca}$ and $\mathrm{Mg}$ ) and $\mathrm{K} / \mathrm{Na}$ ratio significantly $(\mathrm{P}<0.001)$ decreased in roots and shoots with increasing salinity. The higher sodium $(\mathrm{Na})$ concentrations were recorded in shoots than in roots. The different biochemical constituents (proline (PRO), total soluble carbohydrates $(\mathrm{CH})$, soluble proteins (PR) and total free amino acids (FAA)) and non-enzymatic antioxidants compounds (total phenolic (TP) and flavonoids (FLA) contents) significantly $(\mathrm{P}<0.001)$ increased from $50 \mathrm{mM} \mathrm{NaCl}$. The main strategy in $\mathrm{cv}$. gana seems to increase osmotic adjustment through high accumulation of $\mathrm{CH}, \mathrm{PR}, \mathrm{FAA}$ and PRO in the leaves and they could eventually be considered as biochemical indicators of early selection and osmotic adjustment ability for salt tolerant plants. The gana variety could be encouraged to be planted on salt affected soils for the better development in salty areas.
\end{abstract}

Keywords: Dioscorea rotundata; growth parameters; salinity; biochemical constituents; mineral distribution

\section{Introduction}

Salinity is the main abiotic stress, which reduces plant yield in the world $[1,2,3]$. About $7 \%$ of the world's land surface, $5 \%$ of the cultivated land and $20 \%$ of irrigated land has suffered from salt problem [4]. The causes of salinization are the saline parent bed rocks, mineral degradation, invasion of sea water in coastal regions and the over use of saline water irrigation [3,5]. Soil salinity supply modifies ion transport and plant organ content [6]. $\mathrm{NaCl}$ is the main cause of soil salinization and sodium is toxic to cell metabolism. It adversely affects the functioning of some cellular enzymes, plant germination, growth and yield, in higher concentration. It also causes osmotic imbalance, membrane disorganization, reduction in growth, water up take, inhibition of cell division and expansion [2, 5, 7]. The effects of $\mathrm{NaCl}$ on growth, mineral uptake, photosynthesis, biochemical constituent and productivity were published by many authors $[2,3,8,9]$. They showed that sodium $(\mathrm{Na})$ inhibits potassium $(\mathrm{K})$, calcium $(\mathrm{Ca})$ and magnesium $(\mathrm{Mg})$ in plant organs

\footnotetext{
* Corresponding author: Ndouma Mbondjo Cécile

Department of Botany, Faculty of Science, The University of Douala, P.O. Box 24157, Douala-Cameroon, Phone: 00237654047467.

Copyright (C) 2020 Author(s) retain the copyright of this article. This article is published under the terms of the Creative Commons Attribution Liscense 4.0.
} 
which results in $\mathrm{K}^{+} / \mathrm{Na}^{+}$antagonisms. They also reported that photosynthetic activity is strongly affected by salinity stress which is directly related to the closure of stomata due to low intercellular $\mathrm{CO}_{2}$ levels [10]. The results from these salinity treatments have shown increased the concentrations of carbohydrates, proteins, amino acids and proline. Such salt tolerance is determined by osmotic adjustment, the maintenance of ion homeostasis, the control of ion and water flux, the specific protein and free radical enzymes involved in the protection of protoplast functions [11]. Proline (PRO) is the main amino acid in the cytoplasm that contributes to the stability of the osmotic pressure of ions in the vacuoles. Under saline conditions, PRO is the main compatible solute which accumulates and performs well in the process of adapting cells to cold, salt and water stress [12]. Proteins (PR) are involved in osmotic adjustment; they are stored as nitrogen under salt-stress and re-used when the stress is removed [13]. Previous authors showed that salt-tolerant plants store more soluble carbohydrates $(\mathrm{CH})$ under salt stress conditions [14]. The production and accumulation of free amino acids (FAA) by plant tissue during drought, salt and water stress is an adaptive response according to [12]. Total phenolic (TP) and flavonoids (FLA) compounds are a group of secondary metabolites which play a key role between plant, surrounding environment and they are implicated to stress resistance against biotic and abiotic factors [15]. Their accumulation during stress could be cellular adaptive mechanisms for scavenging oxygen free radicals [16].

White yam (Dioscorea rotundata (L) var. gana) is an important cash crop ranked as third tubers produced after cassava and cocoyam in Cameroon. They can be consumed according to the varied ways by cooking, fried or roasted [17]. Tubers improve human health by supplying the much needed proteins and micronutrients vitamin $\mathrm{C}$ and D as well as a lot of potassium. Investigating on crop plant species or with genetic potential for salinity tolerance are better approaches for developing salt tolerant cash crop cultivars [18]. Therefore the aim of this work is to study the effects of NaCl on growth, mineral uptake, chlorophyll contents, biochemical constituents and non-enzymatic antioxidant compounds of white yam (Dioscorea rotundata (L) var. gana). Comparison of these parameters can be helpful to provide additional information on the mechanism of salt tolerance and improve salt tolerant plants for research and breeding program.

\section{Material and methods}

\subsection{Study area}

The study was performed in a greenhouse of the Faculty of Science of the University of Douala in Cameroon, Campus II, from September 2019 to June 2020. Douala ( $3^{\circ} 40^{\prime}-4^{\circ} 01 \mathrm{~N}$ and $9^{\circ} 16-9^{\circ} 52^{\prime}$ E, elevation $13 \mathrm{~m}$ ) is the economic capital of Cameroon, located at the Wouri estuary and belongs to the Northern equatorial climate zone with a particular climate call Cameroonian equatorial climate type characterized with two seasons: (i) a dry season from December to March and (ii) rainy season that runs from March to December. The maximum rain fall is from July to September. Average rain fall and temperature are $400 \mathrm{~mm} /$ year and $26.7{ }^{\circ} \mathrm{C}$ and relative humidity is nearest to $100 \%$ [19]. Prevailing wind carries the Monsoon.

\subsection{Plant material}

White yam (Dioscorea rotundata (L) var. gana) grows well in the limit of the tropical forest and the savannah [17]. The roots can reach $2.5 \mathrm{~m}$ in length in the soil and is used as medicine and for food consumption. The samples were provided by the Institute of Agronomic Research and Development (IRAD) breeding program of Cameroon.

\subsection{Plant growth and treatment}

After breaking dormancy, the samples of white yam variety "gana" were sterilized with 3\% of sodium hypochlorite during 15 minutes, washed five times with demineralized water and transplanted into 5 L polythene bags filled with 5 $\mathrm{kg}$ of sterilized sand. The plants were arranged in a complete randomized block design, with one plant each and five replications per treatment. They were enriched on daily basis with a modified nutrient solution. (in $\mathrm{g} / \mathrm{L}$ ) made of $150 \mathrm{~g}$ $\mathrm{Ca}\left(\mathrm{NO}_{3}\right.$ 2, $70 \mathrm{~g} \mathrm{KNO}_{3}, 15 \mathrm{~g}$ Fe-EDTA, $0.14 \mathrm{~g} \mathrm{KH}_{2} \mathrm{PO}_{4}, 1.60 \mathrm{~g} \mathrm{~K}_{2} \mathrm{SO}_{4}, 11 \mathrm{~g} \mathrm{MgSO}_{4}, 2.5 \mathrm{~g} \mathrm{CaSO}_{4}, 1.18$ g MnSO $4,0.16$ g ZnSO , $3.10 \mathrm{~g} \mathrm{H}_{3} \mathrm{BO}_{4}, 0.17 \mathrm{~g} \mathrm{CuSO}_{4}$ and $0.08 \mathrm{~g} \mathrm{MOO}_{3}$ [20]. The $\mathrm{pH}$ of the nutrient solution was adjusted to 7.0 by adding $\mathrm{HNO}_{3}$ $0.1 \mathrm{mM}$. White yams plants were subjected to different salt concentrations (0 (control), 50, 100 and $200 \mathrm{mM} \mathrm{NaCl}$ ) in culture medium for a period of six weeks for the determination of physiological and biochemical responses of cultivars to salt stress. The average day and night temperatures in the greenhouse were between 26 and $20^{\circ} \mathrm{C}$ respectively during the growth period with an average relative air humidity of $69.5 \%$. Parameters were evaluated under greenhouse condition: growth parameters (dry biomass of roots and shoots, biochemical constituents (soluble proteins, carbohydrates, total free amino acids and proline content) as well as mineral ( $\mathrm{Na}, \mathrm{K}, \mathrm{Ca}$ and $\mathrm{Mg}$ contents of roots and shoots). 


\subsection{Growth parameters}

After the plants were harvested, the number of leaves, stem height, leaf area, noose diameter and dry biomass were recorded. Roots and shoots were separately dried at $60{ }^{\circ} \mathrm{C}$ during 72 Hours and their dry biomasses were determined. Leaf area was calculated using the Taillièz and Ballo formula [21]. Surface area $\left(\mathrm{cm}^{2}\right)=1 / 3$ (Length $\times$ Width). The stem height and noose diameter were determined by measuring with a ruler and vernier caliper respectively, and the number of leaves were determined by counting.

\subsection{Mineral content}

In order to determine the mineral distribution of $\mathrm{Na}, \mathrm{K}, \mathrm{Ca}$ and $\mathrm{Mg}$ in the shoots and roots, $1 \mathrm{~g}$ of dry biomass were separately crushed and thoroughly mixed with $20 \mathrm{~mL}$ of $\mathrm{HCl} 1 / 10$ for 24 hours. The sodium, potassium, calcium and magnesium concentrations in plants partitioning were determined through atomic absorption spectrophotometer (Rayleigh WFX-100) [22] method.

\subsection{Chlorophyll content}

The chlorophyll content was determined using the Arnon [23] method. $0.80 \mathrm{~g}$ sample of fresh leaves were crushed and their contents extracted with $80 \%$ of alkaline acetone $(\mathrm{v} / \mathrm{v})$ and the filtrate was analyzed with spectrophotometer (Pharmaspec model UV-1700) at 645 and $663 \mathrm{~nm}$ wavelengths.

\subsection{Biochemical constituents}

\subsubsection{Proline content}

Proline content (PRO) was estimated using Bates et al. [24] method. $0.5 \mathrm{~g}$ of fresh leaves were weighed and put inside a flask. $10 \mathrm{~mL}$ of $3 \%$ aqueous sulphosalicylic acid was poured in the same flask. The mixture was homogenized, and then filtered with a Whatman No2 filter paper. $2 \mathrm{~mL}$ of filtered solution was poured into a test tube, and then $2 \mathrm{~mL}$ of glacial acetic acid and ninhydrin acid were respectively added into the same tube. The test tube was heated in a warm bath for $1 \mathrm{~h}$. The reaction was stopped quenched by placing the test tube in an ice bath. $4 \mathrm{~mL}$ of toluene was added to the test tube and stirred. The toluene layer was separated at room temperature, and the mixture purple color was read at 520 $\mathrm{nm}$ by spectrophotometer UV (Pharmaspec model UV-1700). At $520 \mathrm{~nm}$, the absorbance was recorded and the concentration of PRO was determined using a standard curve as $\mu \mathrm{g} / \mathrm{g} \mathrm{FW}$.

\subsubsection{Total free amino acids content}

Total free amino acids content (FAA) was determined by the ninhydrin method [25]. Fresh leaves (1 g) were grounded in $5 \mathrm{~mL}$ of ethanol 80\%, amino acids were then extracted using reflux technique in boiling ethanol for 30 min. After decanting, the supernatant was filtered using Whatman $\mathrm{N}^{\circ} 3$ filter paper. The filtrate was collected and the residue used to repeat the extraction. The two mixed filtrates constituted the raw extract of amino acids that were measured using ninhydrin method. The absorbance of purplish bruise complex was read at $570 \mathrm{~nm}$ wavelength. The standard curve was established using $0.1 \mathrm{mg} / \mathrm{mL}$ of glycine.

\subsubsection{Soluble proteins content}

Soluble proteins content (PR) was evaluated using Bradford [26] method. The protein standard protein used was the bovine serum albumin (BSA). $0.1 \mathrm{~g}$ of fresh leaves were homogenized with $4 \mathrm{~mL}$ of an already prepared sodiumphosphate buffer, $\mathrm{pH}$ 7.2. The mixture was then centrifuged at $13000 \mathrm{rpm}$ for $4.5 \mathrm{~min}$ at $4^{\circ} \mathrm{C}$. $1 \mathrm{~mL}$ of the supernatant was poured into a tube containing $5 \mathrm{~mL}$ of the Bradford reagent. The mixture was shook and incubated in the dark for $15 \mathrm{~min}$. The absorbance of the resulting blue complex was read at $595 \mathrm{~nm}$ with a spectrophotometer UV (PG instruments T60). The standard curve was obtained using BSA $1 \mathrm{mg} / \mathrm{mL}$.

\subsubsection{Soluble carbohydrate content}

Soluble carbohydrate $(\mathrm{CH})$ content was obtained using phenol-sulphuric acid [27]. The fresh leaves (1 g) were grounded in $5 \mathrm{~mL}$ of $80 \%$ ethanol twice and filtered with the whatman No 2 filter paper. The collected extracts were diluted by deionized water to $50 \mathrm{~mL}$. $1 \mathrm{~mL}$ of each sample was poured in test tube, then $1 \mathrm{~mL}$ of phenol solution and $5 \mathrm{~mL}$ of sulphuric acid were added. The mixture was then swirled. The wavelength was read at $490 \mathrm{~nm}$ by a spectrophotometer (Pharmaspec UV-1700 model). The quantity of $\mathrm{CH}$ was deduced from the glucose standard curve. 


\subsection{Non enzymatic antioxidants}

\subsubsection{Total phenolic content}

Total phenolic content (TP) was determined using the folin-ciocalteu method [28]. $1 \mathrm{~g}$ of fresh leaves were grounded at $4{ }^{\circ} \mathrm{C}$ during 20 minutes in $3 \mathrm{~mL}$ of $0.1 \mathrm{NHCl}$, the homogenate was centrifuged at $6000 \mathrm{~g}$ during $40 \mathrm{minutes}$. The pellet re-suspended in $3 \mathrm{~mL}$ of $0.1 \mathrm{NHCl}$ and centrifuges previously. The two supernatant are mixed and constitute the crude extract of soluble phenol. The reaction mixture containing $15 \mu \mathrm{L}$ of extract $100 \mu \mathrm{L}$ folin-ciocalteu reagents, $0.5 \mathrm{~mL}$ of $20 \% \mathrm{Na}_{2} \mathrm{CO}_{3}$ was incubated at $40{ }^{\circ} \mathrm{C}$ for 20 minutes and absorbance read at $720 \mathrm{~nm}$ wavelength with a spectrophotometer (Pharmaspec UV-1700 model). The TP (mg/g FW) content was determined through a standard curve established by using chlorogenic acid.

\subsubsection{Flavonoids content}

Flavonoids content (FLA) of crude extract was determined by the aluminum chloride colorimetric method [29]. $50 \mu \mathrm{L}$ of crude extract ( $1 \mathrm{mg} / \mathrm{mL}$ ethanol) were made up to $1 \mathrm{~mL}$ with methanol, mixed with $4 \mathrm{~mL}$ of distilled water and then $0.3 \mathrm{~mL}$ of $5 \% \mathrm{NaNO}_{2}$ solution; $0.3 \mathrm{~mL}$ of $10 \% \mathrm{AlCl}_{3}$ solution was added after 5 minutes of incubation, and the mixture was allowed to stand for 6 minutes. Then, $2 \mathrm{~mL}$ of $1 \mathrm{~mol} / \mathrm{L} \mathrm{NaOH}$ solution were added, and the final volume of the mixture was brought to $10 \mathrm{~mL}$ with double-distilled water. The mixture was allowed to stand for $15 \mathrm{~min}$, and absorbance was recorded on spectrophotometer (Pharmaspec UV-1700 model) at $510 \mathrm{~nm}$ wavelength. FLA content was calculated from a grutin calibration curve, and the result was expressed as grutin equivalent per g dry weight.

\subsection{Statistical analysis}

The experiment was performed in a complete randomized design. All data were presented in terms of mean $( \pm$ standard deviation), statistically analysed using Graph pad Prism version 5.01 and subjected to analysis of variance (ANOVA). Statistical differences between treatment means were established using the Fisher Least Significant Difference (LSD) at $\mathrm{P}<0.05$.

\section{Results and discussion}

\subsection{Plant growth}

The growth parameters (stem height, number of leaves, noose diameter, leaf area and dry biomass) were generally influence by the intake doses of $\mathrm{NaCl}$ and decreased significantly in the culture medium during six weeks from 100 to $200 \mathrm{mM}$ of $\mathrm{NaCl}$ (Table 1). Noose diameter and number of leaves significantly decrease $(\mathrm{P}<0.05)$ from $100 \mathrm{mM}$ of $\mathrm{NaCl}$, leaf area significantly decreased $(\mathrm{P}<0.01)$ while dry biomass and stem height significantly decreased $(\mathrm{P}<0.001)$ from $100 \mathrm{mM}$ of $\mathrm{NaCl}$ (Table 1). These results are in consonance with those of Amira and Abdul Qados [30] on Vicia faba; Assimakopoulou et al. [31] on Phaseolus vulgaris and Hand et al. [3] on Capsicum annuum L. They showed that, the number of leaves decreased with the intake doses of $\mathrm{NaCl}$ due to the accumulation of $\mathrm{Na}^{+}$in the cytoplasm of leaves. At the same time their fluid vacuoles cannot store salt and consequently decrease the salt concentrations in the cell and finally the leaves fell and died. According to Dadkhah [32] on Beta vulgaris L and Hand et al. [3] on Capsicum annuum L, the decrease of noose diameter with intake doses of $\mathrm{NaCl}$ is a consequence of physiological responses like the modification of ionic equilibrium, mineral nutrition disruption which inhibited the accumulation of mineral ions in the tissues. Mudgal et al. [33] and Hand et al. [3] adhere to the fact that the decrease in leaf area with the intake doses of $\mathrm{NaCl}$ in the culture medium is the consequence of several physiological responses including modification of ion balance, stomatal behavior, mineral nutrition and photosynthetic efficiency. According to Erum Mukhtar et al. [34] on Brassica napus L; Hand et al. [3] on Capsicum annuum L, the decrease of stem height under salinity stress can be due to the negative effects of salt on photosynthetic activities (Table 1). In additional, the disturbance of enzymatic activity affects the synthesis of proteins consequently induces the reduction of carbohydrates and growth hormones, the reduction of the plant turgidity and the competition of ions ensure the osmotic adjustment [35]. The results obtained showed a significant $(\mathrm{p}<0.001)$ decrease in dry biomass of white yam in the culture medium from $100 \mathrm{mM} \mathrm{NaCl}$ in shoots and roots (Table 1). These results are similar with those obtained by Taffouo et al. [8]; Meguekam et al. [9]; Nouck et al. [2] and Hand et al. [3] respectively on Vigna unguiculata L. Walp, Arachis hypogaea L., Lycopersicum esculentum L. and Capsicum annuum L. They showed that the reduction of photosynthetic capacity can reduce the shoots and roots dry biomass. According to Hamrouni et al. [36] plant can tolerate the salinity stress by first reducing their root system in the aim to maintain the leaves and ensure their photosynthetic activity. 
Table 1 Effects of $\mathrm{NaCl}$ on plant growth in white yam after six weeks of treatment.

\begin{tabular}{|c|c|c|c|c|c|c|c|}
\hline \multirow[b]{2}{*}{ Cultivar } & \multirow{2}{*}{$\begin{array}{l}\text { Treatment } \\
\text { mM NaCl }\end{array}$} & \multicolumn{2}{|r|}{ Dry Biomass (g) } & \multirow[b]{2}{*}{ ND (mm) } & \multirow[b]{2}{*}{$\mathrm{SH}(\mathrm{cm})$} & \multirow[b]{2}{*}{ NL } & \multirow[b]{2}{*}{$\mathrm{LA}\left(\mathrm{cm}^{2}\right)$} \\
\hline & & RDB & SDB & & & & \\
\hline & 0 & $19.50 \pm 1.45$ & $79.81 \pm 5.63$ & $2.95 \pm 0.14$ & $53.28 \pm 3.18$ & $9.22 \pm 0.49$ & $25.53 \pm 2.89$ \\
\hline \multirow{3}{*}{ gana } & 50 & $17.86 \pm 1.95^{\mathrm{a} n s}$ & $78.88 \pm 4.19$ ans & $2.83 \pm 0.1^{\mathrm{a} n s}$ & $39.15 \pm 2.55^{\mathrm{a} * * *}$ & $9.02 \pm 0.33^{\mathrm{a} n s}$ & $23.58 \pm 2.04^{\mathrm{a} n s}$ \\
\hline & 100 & $12.86 \pm 1.50^{\mathrm{b} * * *}$ & $62.39 \pm 5.46^{\mathrm{b} * * *}$ & $2.73 \pm 0.09 \mathrm{~b} *$ & $33.69 \pm 1.99 \mathrm{~b} * * *$ & $8.69 \pm 0.41^{b *}$ & $19.36 \pm 2.51^{\mathrm{b} * *}$ \\
\hline & 200 & $10.44 \pm 0.89^{\mathrm{b} * * *}$ & $48.31 \pm 3.19^{\mathrm{c} * * *}$ & $2.61 \pm 0.09^{\mathrm{c} *}$ & $28.75 \pm 1.76^{\mathrm{c} * * *}$ & $5.52 \pm 0.59^{c * * *}$ & $14.79 \pm 2.74 \mathrm{c} * * *$ \\
\hline
\end{tabular}

Mean results of five replications \pm SD. Based on the ANOVA method followed by all pairwise analysis using the student-Newman-keuls. nsP $>0.05 ; * \mathrm{P}<0.05 ; * * \mathrm{P}<0.01$ and ${ }^{* * *} \mathrm{P}<0.001$ as compared to 0 $\mathrm{mM} \mathrm{NaCl}$. Letter showed the difference between the different concentrations $(\mathrm{P}<0.05)$.

Table 2 Effects of $\mathrm{NaCl}$ on mineral distribution ( $\mu \mathrm{g} / \mathrm{g} \mathrm{MS})$ in white yam after six weeks of treatment.

\begin{tabular}{|c|c|c|c|c|c|c|}
\hline & Treatment & & $\begin{array}{ll}\text { Mineral distribution } \\
(\mu \mathrm{g} / \mathrm{g} \text { MS })\end{array}$ & & & \\
\hline Cultivar & $\mathrm{mM} \mathrm{NaCl}$ & $\mathrm{Na}^{+}$ & $\mathrm{K}^{+}$ & $\mathrm{Ca}^{2+}$ & $\mathrm{Mg}^{2+}$ & $\mathrm{K}^{+} / \mathrm{Na}^{+}$ \\
\hline \multirow{5}{*}{ Roots } & 0 & $71.60 \pm 4.68$ & $37.74 \pm 2.40$ & $33.47 \pm 3.25$ & $26.37 \pm 3.18$ & 0.524 \\
\hline & 50 & $89 . \pm 5.18^{\mathrm{a} *}$ & $31.25 \pm 2.56^{\mathrm{a} * *}$ & $29.68 \pm 3.39 \mathrm{a} n s$ & $22.49 \pm 2.81^{\mathrm{a} n s}$ & 0.344 \\
\hline & 100 & $110.81 \pm 9.25^{\mathrm{b} * * *}$ & $26.46 \pm 2.10^{\mathrm{b} * * *}$ & $26.26 \pm 2.75^{\mathrm{ab} *}$ & $19.44 \pm 1.73^{\mathrm{a} * *}$ & 0.234 \\
\hline & 200 & $136.33 \pm 13.03^{\mathrm{c} * * *}$ & $19.30 \pm 2.44^{\mathrm{c} * * *}$ & $20.78 \pm 3.77^{\mathrm{b} * * *}$ & $18.22 \pm 2.20^{\mathrm{a} * *}$ & 0.138 \\
\hline & 0 & $182.51 \pm 12.79$ & $102.39 \pm 9.40$ & $88.62 \pm 7.82$ & $73.42 \pm 4.61$ & 0.556 \\
\hline \multirow{3}{*}{ Shoots } & 50 & $211.82 \pm 18.71^{\mathrm{a} *}$ & $91.22 \pm 7.72^{\text {ans }}$ & $81.31 \pm 3.54^{\mathrm{a}} \mathrm{ns}$ & $65.68 \pm 4.98^{\mathrm{a} n s}$ & 0.428 \\
\hline & 100 & $247.84 \pm 16.51^{\mathrm{b} * * *}$ & $76.48 \pm 6.72^{\mathrm{b} * * *}$ & $75.37 \pm 4.18^{\mathrm{a} * *}$ & $55.66 \pm 5.95^{\mathrm{b} * * *}$ & 0.302 \\
\hline & 200 & $310.31 \pm 15.66^{\mathrm{b} * * *}$ & $70.68 \pm 4.45^{\mathrm{b} * * *}$ & $64.75 \pm 4.14 \mathrm{~b} * * *$ & $44.30 \pm 3.69 \mathrm{c} * * *$ & 0.222 \\
\hline
\end{tabular}

Mean results of five replications $\pm \mathrm{SD}$. Based on the ANOVA method followed by all pairwise analysis using the student-Newman-keuls. nsP $>0.05 ;{ }^{*} \mathrm{P}<0.05 ;{ }^{* *} \mathrm{P}<0.01$ and ${ }^{* * *} \mathrm{P}<0.001$ as compared to 0 $\mathrm{mM} \mathrm{NaCl}$. Letter showed the difference between the different concentrations $(\mathrm{P}<0.05)$. 


\subsection{Nutrient uptake}

Salt treatments significantly $(\mathrm{p}<0.001)$ increased $\mathrm{Na}^{+}$with the increase doses of $\mathrm{NaCl}$ (Table 2). These results are the same with those observed by Taffouo et al. [8]; Mehede et al. [37] and Hand et al. [3]. They showed that the predominance of salts enhances $\mathrm{Na}^{+}$uptake and this inhibits the uptake of other mineral elements like $\mathrm{K}^{+}$. Additional white yam "gana" transfer $\mathrm{Na}^{+}$from the root to the aerial parts. These results corroborate those obtained by Wamba et al. [38] and Rais et al. [5] who showed that the competition between $\mathrm{Na}^{+}$and $\mathrm{K}^{+}$for aerial parts of plants can be caused by the loss of osmotic potential of root medium, specific ion toxicity and the lack of nutritional ions. Increase in the mineral content, increases with the increasing concentrations in $\mathrm{NaCl}$ with a greater accumulation in the shoots related to the roots. From the results obtained, $\mathrm{Ca}^{2+}$ significantly decreased in the culture medium with the intake doses of $\mathrm{NaCl}$. According to Amuthavalli et al. [39] and Rahman et al. [40], calcium plays an important role in the osmotic adjustment process. The calcium also plays an important role by reducing the negative effect of $\mathrm{NaCl}$ and increasing the selectivity $\mathrm{K}^{+} / \mathrm{Na}^{+}[41,42]$. The decrease of magnesium with the intake doses of $\mathrm{NaCl}$ is according to Assimakopoulou et al. [31], higher accumulation of $\mathrm{Na}^{+}$in the soil could be the cause of toxicity, ionic disorder and the competition between ions which inhibited the translocation of other minerals $\mathrm{CK}^{+}, \mathrm{Ca}^{2+}$ and $\mathrm{Mg}^{2+}$ which play a major role in the membrane permeability) to the aerial part of the plant.

\subsection{Chlorophyll content}

The different chlorophyll, $\mathrm{a}, \mathrm{b}$ and $(\mathrm{a}+\mathrm{b})$ are highest at $0 \mathrm{mM} \mathrm{NaCl}$ and slopes down significantly $(\mathrm{p}<0.001)$ with increase intake doses of $\mathrm{NaCl}$ (Fig. 1). This decrease in chlorophyll content under salt stress is a commonly reported phenomenon in diverse studies, because of its adverse effects on membrane stability. This was observed by $[3,8,43]$. These authors reported that chlorophyll content $\mathrm{a}, \mathrm{b}$ and total decreases with increasing salt concentrations. The decrease in chlorophyll content was observed because of salt-induced weakening of protein pigment-complex and increase chlorophyllase (EC: 3:1.1.14) [35].

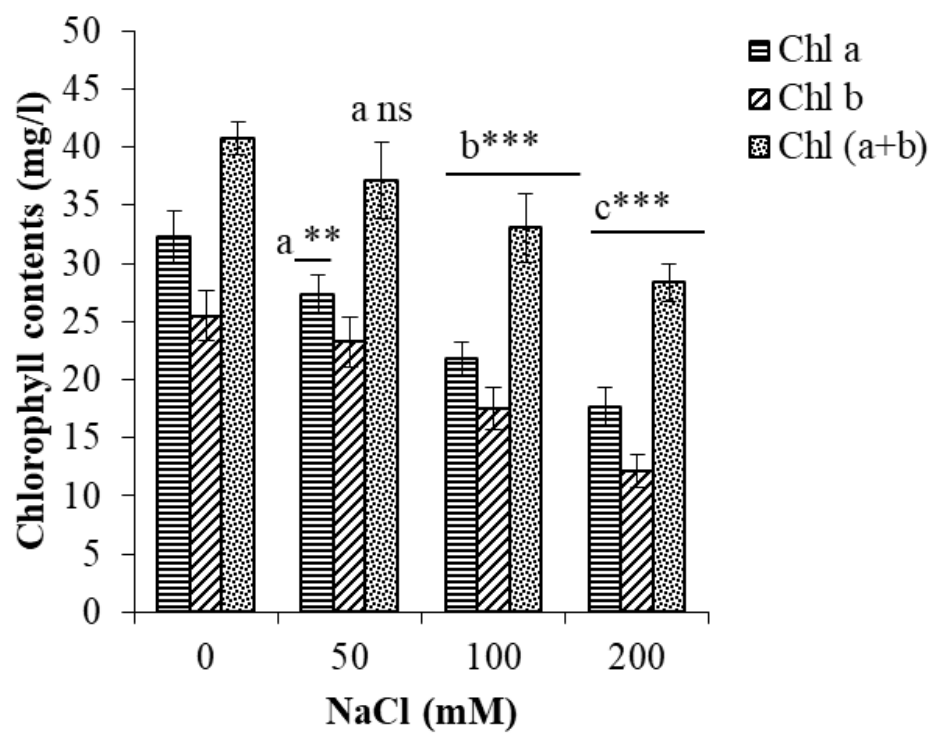

Figure 1 Effects of $\mathrm{NaCl}$ concentrations on the chlorophyll content $\mathrm{a}, \mathrm{b},(\mathrm{a}+\mathrm{b})$ of white yam. Mean results of five replications \pm SD. Based on the ANOVA method followed by all pairwise analysis using the student-Newman-keuls. nsP $>0.05$; ${ }^{* *} \mathrm{P}<0.01$ and ${ }^{* * *} \mathrm{P}<0.001$ as compared to $0 \mathrm{mM} \mathrm{NaCl}$. Letter showed the difference between the different concentrations $(\mathrm{P}<0.05)$.

\subsection{Non-enzymatic antioxidant}

Results obtained on the effect of salinity on the accumulation of flavonoids agree with those of Salama et al. [44] who studied genotypic variations in phenolic, flavonoids and their antioxidising activities in maize plant grown in salinized media (Fig. 2). This study showed that an increase in salt concentrations led to a significant increase in total phenol and flavonoids contents. According to Hichem et al. [45] High accumulation of phenolics in plants is physiologically important in overcoming the salinity-induced oxidative stress. These results agree with those of Radi et al. [46] who reported that salinity stress affects the phenolic compounds content by the induced disturbance of the metabolic processes leading to an increase in phenolic compounds. 

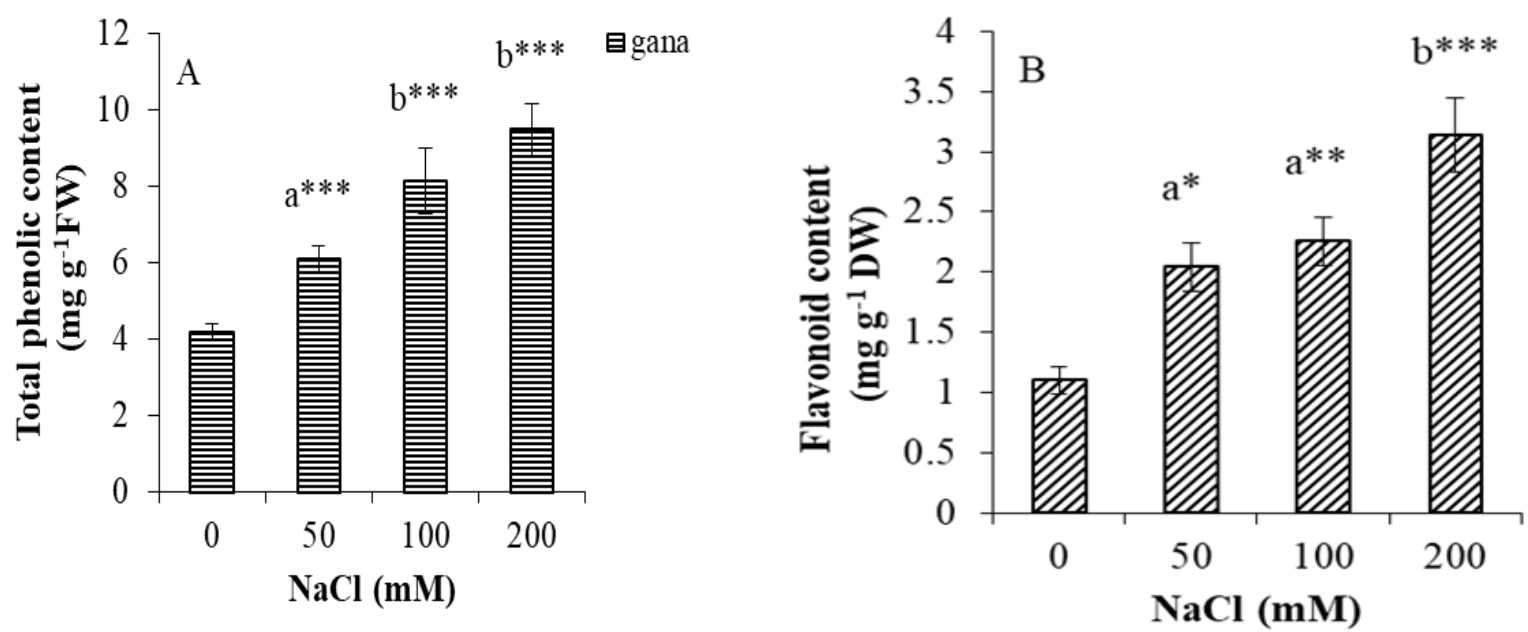

Figure 2 Effects of $\mathrm{NaCl}$ on accumulation of non-enzymatic antioxidants in white yam. A: Total phenolic content; B:

Flavonoid content.

\subsection{Biochemical constituents}

The total soluble proteins significantly increased with intake doses of $\mathrm{NaCl}$ (Fig. 3). The same results were obtained by Kapoor and Srivastava [47] ; Amira and Abdul [30]; Nouck et al. [2] and Hand et al. [3] they showed that the accumulation of soluble proteins in plant tissues under conditions of environmental stress was due to regulatory osmotic adjustment in current stress.
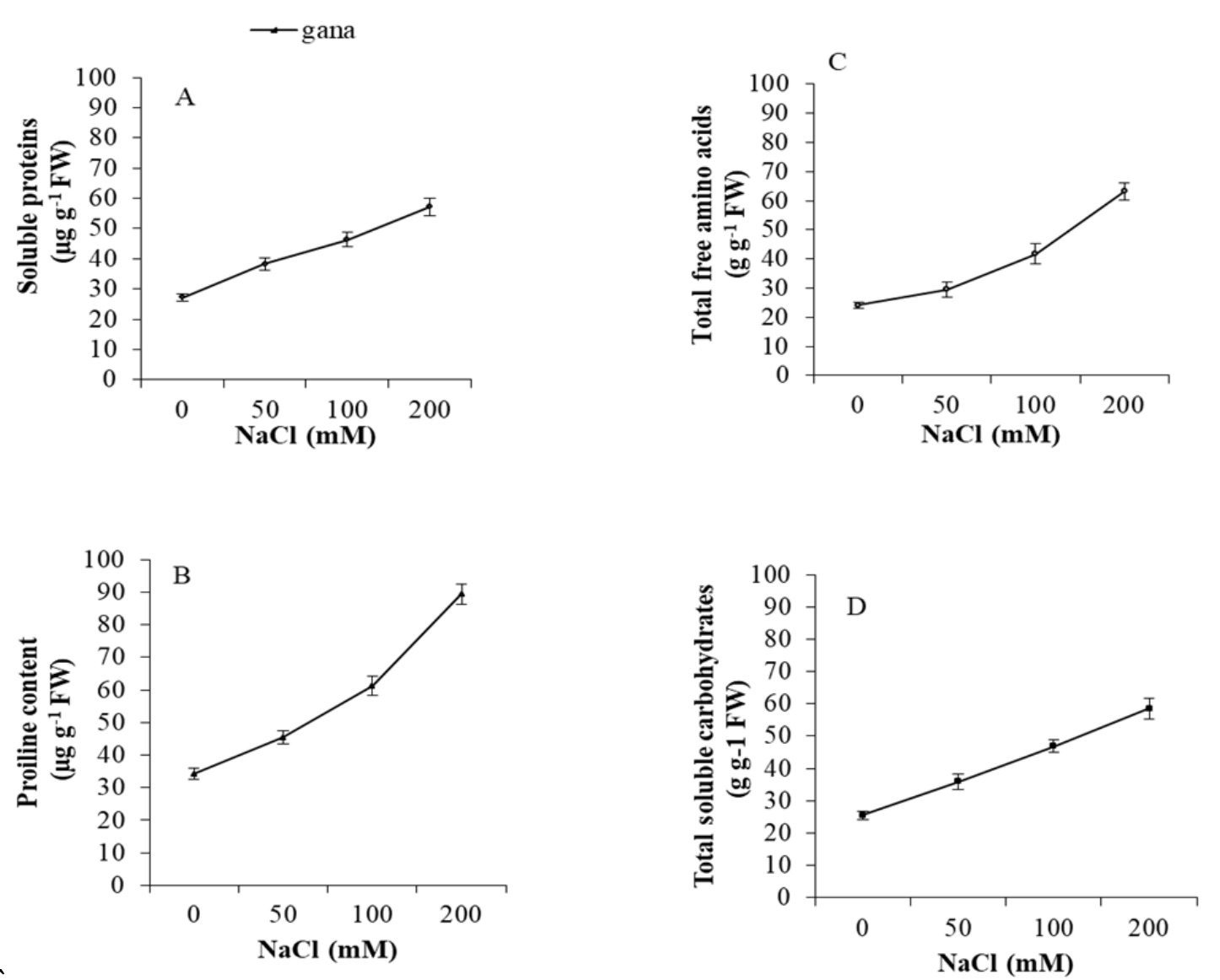

Figure 3 Effects of $\mathrm{NaCl}$ on accumulation of biochemical constituents in white yam. A: Total soluble proteins; B: Proline content; C: Total free amino acids and D: Soluble carbohydrates. Bars are means $(n=5) \pm S D$. 
The osmotic balance of the cytoplasm relies on an active synthesis of organic compounds as total soluble proteins which enhance the plant salt tolerance. The total free amino acids in leaves increase with increase NaCl concentrations (Fig. 3). Similarly, Cusido et al. [48] and Nouck et al. [2] reported that salinity increased the levels of total free amino-acids and may be a good indicator for screening salt-tolerant genotypes. In addition this is because the increase of free aminoacids is due to the reduction of osmotic potential to maintain the turgid potential. From the results obtained the total soluble carbohydrates increase significantly with intake doses of $\mathrm{NaCl}$ (Fig. 3). According to Dhanapackiam and Llyas [49] and Movafegh et al. [43], the accumulation of total soluble carbohydrates in plant tissues under conditions of environmental stress was due to regulatory osmotic adjustment in current stress. The osmotic balance of the cytoplasm relies on an active synthesis of organic compounds such as soluble carbohydrates which enhances the plant salt tolerance. The results showed that the proline increased significantly with intake doses of $\mathrm{NaCl}$ (Fig. 3). According to Meguekam et al. [9]; Shah et al. [50] and Nouck et al. 2, the build-up of Proline (PRO) is a method of stress tolerance because its accumulation contributes to the acquisition of tolerance by maintaining turgor in cells of many species responsible for osmotic adjustment in tolerant plants grown under saline conditions

\section{Conclusion}

The results of this study showed that white yam (Dioscorea rotundata (L) var. gana) was affected by the supply of intake doses of $\mathrm{NaCl}$ for a period of six weeks in the culture medium. The dry biomass (roots and shoots), the growth parameters (number of leaves, stem height, leaf area and noose diameter) and chlorophyll contents decreased from 100 $\mathrm{mM}$ of $\mathrm{NaCl}$. The biochemical constituents (Proline, total soluble carbohydrates, soluble proteins and total free amino acids) and non-enzymatic antioxidant compounds (Total phenolic and flavonoids compounds) increased from $50 \mathrm{mM}$ of $\mathrm{NaCl}$. The main strategy of salt-tolerance in gana seems to increase osmotic adjustment through the strongly accumulation of PR, CH, PRO and FAA in leaves. Thus, the higher accumulation of these compatible solutes, TP and FLA in leaves could be considered as potential biochemical indicators of early identification and osmotic adjustment ability for salt-tolerant plants in salt stress conditions. The mineral ions ( $\mathrm{Na}, \mathrm{K}, \mathrm{Ca}, \mathrm{Mg}$ and $\mathrm{K} / \mathrm{Na}$ ) in the plant partitioning (roots and shoots) were significantly decreased with increasing $\mathrm{NaCl}$, and the highest concentrations of $\mathrm{Na}$ were observed in the shoot than roots.

\section{Compliance with ethical standards}

\section{Acknowledgments}

The author thanks Dr Fokom and Dr Adamu of the biotechnology center of Nkolbisson for their excellent technical assistance.

\section{Disclosure of conflict of interest}

There is no conflict of interest.

\section{References}

[1] Ashraf M, Foolad MA. Improving plant abiotic stress resistance by exogenous application of osmoprotectants glycine betaine and proline. Environmental and Experimental Botany. 2007; 59(2): 206-216.

[2] Nouck AE, Taffouo VD, Tsoata E, Dibong SD, Nguemezi ST, Gouado I, Youmbi E. Growth, Biochemical Constituents, Micronutrient Uptake and Yield Response of Six Tomato (Lycopersicum esculentum L.). Journal of Agronomy. 2016; 15(2): 58-67.

[3] Hand MJ, Taffouo VD, Nouck AE, Nyemene KPJ, Tonfack LB, Meguekam TL, Youmbi E. Effects of Salt Stress on Plant Growth, Nutrient Partitioning, Chlorophyll Content, Leaf Relative Water Content, Accumulation of Osmolytes and Antioxidant Compounds in Pepper (Capsicum annuum L.) Cultivars. Notulae Botanicae Horticulture Cluj-Napoca Agrobotanici. 2017; 45(2): 481-490.

[4] Ghassemi F, Jakeman AJ, Nix HA. Salinisation of Land and Water Resources. CAB International, Wallingford. 1995; 1-526.

[5] Rais L, Massod A, Inam A, Khan N. Sulfur and nitrogen co-ordinately improve photosynthetic efficiency, growth and proline accumulation in two cultivars of mustard under salt stress. Journal of Plant Biochemistry and Physiology. 2013; 1(1): 101. 
[6] Cramer GR. Uptake and role of ions in salt tolerance. In: Jaiwal PK, Singh RP, Gulati A (eds) Strategies for improving salt tolerance in higher plants. Oxford and IBH publishing Co Pvt Ltd New Delhi. 1997; 55-86.

[7] Alam MZ, Stuchbury TR, Naylor EL, Rashid MA. Effect of salinity on growth of some modern rice cultivar. Journal Agronomy. 2014; 3(1): 1-10.

[8] Taffouo VD, Ekwel SS, Meguekam TL, Nouck AE, Wamba FO, Youmbi E. Changes in growth and nutrient uptake in response to foliar application of sodium and calcium chloride in Cowpea cultivars Vingna unguiculata L.Walp. African Journal of Biotechnology. 2014; 13(47): 4382-4389.

[9] Meguekam TL, Taffouo VD, Grigore MN, Zamfirache MM, Youmbi E, Amougou A. Differential responses of growth, physiological and biochemical characteristics to salt stress in peanut (Arachis hypogaea L.) cultivars. Afrcan Journal of Biotechnology, 2014; 13(50): 4577-4587.

[10] Turan MA, Turkmen N, Taban $\mathrm{N}$. Effect of $\mathrm{NaCl}$ on stomatal resistance and proline, chlorophyll, $\mathrm{Na}, \mathrm{Cl}$ and $\mathrm{K}$ concentrations of lentil plants. Journal of Agronomy. 2007; 6(2): 378-381.

[11] Parida AK, Das AB. Salt tolerance and salinity effects on plants. Ecotoxicology and Environment Safety. 2005; 60(3): 324-349.

[12] Kaviani B. Proline accumulation and growth of soybean callus under salt and water stress. International Journal of Agricultural Biology. 2008; 10(2): 221-223.

[13] Singh P, Singh U, Eggum BO, Kumar KA, Andrews DJ. Nutritional evaluation of high protein genotypes of pearl millet (Pennisetum americanum (L) Leeke). Journal of the Science of Food and Agriculture. 1987; 38(1): 41-48.

[14] Khosravinejad F, Heydari R, Farboodnia T. Effect of salinity on organic solutes contents in barley. Pakistan Journal Biological Science. 2009; 12(2): 158-162.

[15] Bergmann H, Leinhos V, Machelet B. Increase of stress resistance in crop plants by using phenolic compounds. Acta Horticulturae. 1994; 381(50): 390-397.

[16] Mohamed AA, Aly AA. Alternations of some secondary metabolites and enzymes activity by using exogenous antioxidant compound in onion plants grown under seawater salt stress. European Journal of Scientific research.2008; 3(2): 139-146.

[17] Ngue BT, Mbairanodji A, Njualem D. Guide des techniques de production et de conservation d'ignames (Dioscorea spp.). Programme national de développement des racines et tubercules. 2007; 1-31.

[18] Munns R, Tester M. Mechanisms of salinity tolerance. Annual Review of Plant Biology. 2008; 59(1): 651-681.

[19] Din N, Saenger P, Priso JR, Dibong SD, Amougou A. Logging activities in mangrove forests: A case studies of Douala Cameroon. African journal of Environmental Science and Technology. 2008; 2(2): 22-30.

[20] Hoagland DR, Arnon DI. The water-culture method for growing plants without soil. University of California, College of Agriculture, Berkley. 1950; 1-34.

[21] Taillièz, Ballo Koffi. Une méthode de mesure de la surface foliaire du palmier á huile. Oléagineux. 1992; 47(8-9): 537-553.

[22] Pauwels JM, Van Ranst E, Verloo M, Mvondo ZA. Analysis methods of major plants elements. Pedology Laboratory manual : Methods of plants and soil analysis. Stock management equipment of worms and chemical equipment. AGCD, Brussels. Agriculture Publications. 1992; 1-28.

[23] Arnon DI. Copper enzymes in isolated chloroplasts. Polyphenylodase in Beta vulgaris. Plant physiology. $1949 ; 24$ (1): 1-15.

[24] Bates L, Waldren RP, Teare ID. Rapid determination of free proline for water-stress studies. Plant and Soil. 1973; 39 (2): 205-207.

[25] Yemm EW, Cocking EC. The determination of amino acids with ninhydrin. The Analyst. 1955; 80: $209-213$.

[26] Bradford MM. A rapid and sensitive method for quantitation of microgram of protein utilizing the principle of protein-dye binding. Analytical Biochemistry Quantitative. 1976; 72(1-2): 248-254.

[27] Dubois M, Gilles KA, Hamil JK, Rebers PA, Smith F. Colorimetric method for determination of sugars and related substances. Anal Chemistry. 1956; 28(3): 350-356.

[28] Marigo G. On a fractionation method and estimation of the phenolic compounds in plant. Analysis. 1973; 2(2): 106-110. 
[29] Chang CC, Yang MH, Wen HM, Chern JC. Estimation of total flavonoid content in propolis by two complementary colorimetric methods. Journal of Food Drug Analysis. 2002; 10(3): 178-182.

[30] Amira MS, Abdul Q. Effect of salt stress on plant growth and metabolism of bean plant (Vicia faba L.). Journal of the Saudi Society of Agricultural Sciences. 2011; 10(1): 7-15.

[31] Assimakopoulou A, Salmas I, Nifakos K, Kalogeropoulos P. Effect of salt stress on three green bean (Phaseolus vulgaris L.) cultivars. Notulae Botanicae Horti Agrobotanici Cluj-napoka. 2015; 43 (1): 113-118.

[32] Dadkhah A. Effect of salinity on growth and leaf photosynthesis of two sugar beet (Beta vulgaris L.) cultivars. Journal of Agriculture Sciences and Technology. 2011; 13(7): 1001-1013.

[33] Mudgal V, Madaan N, Mudgal A. Biochemical mechanisms of salt tolerance in plants: a review. International Journal of Botany. 2010; 6(2): 136-143.

[34] Erum Mukhtar EH, Siddiqi KH, Bratti K, Nawez, Hussain K. Gas exchange attributes can be valuable selection criteria for salinity tolerance in Canola cultivars Brassica napus L. Pakistan Journal of Botany. 2013; 45(S1): 3540.

[35] Taffouo VD, Nouck AE, Dibong SD, Amougou A. Effects of salinity stress on seedlings growth, mineral nutrients and total chlorophyll of some tomato Lycopersicum esculentum L. cultivars. African Journal of Biotechnology. 2010; 9(33): 5366-5372.

[36] Hamrouni L, Hanana M, Abdelly C, Ghorbel A. Exclusion du chlorure et inclusion du sodium : deux mécanismes concomitants de tolérance à la salinité chez la vigne sauvage Vitis vinifera sub sp. sylvestris (var.'sejnène'). Biotechnologie, Agronomie, Société et Environnement. 2011; 15(3): 387- 400.

[37] Mehede HR, Lutful H, Mirza ML, Arif HKB, Alam MDJ. Evaluation of rice genotypes under salt stress at the seedling and reproductive stages using phenotypic and molecular markers. Pakistan journal of botany. 2014; 42(2): 423432.

[38] Wamba OF, Taffouo VD, Youmbi E, Ngwene B, Akoa A. Effects of organic and inorganic nutrients sources on the growth, total chlorophyll and yield of three Bambara Groundnut landraces in the coastal region in Cameroon. Journal of Agronomy. 2012; 11(2): 31- 42.

[39] Amuthavalli P, Anbu D, Sivasankaramoorthy S. Effect of calcium chloride on growth and Biochemical constituents of cotton (Gossypium hirsutum L.) under salt stress. International Journal of Research in Botany. 2012; 2(3): 912 .

[40] Rahman IU, Iqbal Z, Ijaz F, Manan S, Solail Ali, Khan K, Karim S, Qadir G. Growth and yield of Phaseolus vulgaris as influenced by different nutrient treatment in manshera. International journal of agronomy and agriculture research. 2014; 4(3): 20-26.

[41] Liu J, Zhu JK. A calcium sensor homolog requires for plant salt tolerance. Science. 1998; 280(5371): $1943-1945$.

[42] Ekwel SS, Nouck AE, Meguekam TL, Muyan FR, Ngotta BJB, Thiaze IA, Choula F, Ngo Nkot L, Priso RJ, Dibong SD, Ndono D, Taffouo VD. Influence des sols salins et calcaires sur la croissance, la nutition minerale et les composantes agronomiques du niébé (Vigna unguiculata (L) Walp.) dans trois zones agro écologiques du Cameroun. Journal of Applied Biosciences. 2019; 134(2019): 13673-13688.

[43] Movafegh S, Roghie RJ, Shadi K. Effect of salinity stress on chlorophyll content, proline, water soluble carbohydrate, germination, growth and dry weight of three seedling barley (Hordeum vulgare L.) cultivars. Journal of Stress Physiology and Biochemistry. 2012; 8(4): 157-168.

[44] Salama ZA, Gaafar A, El Fouly MM. Genotypic Variations in Phenolic, Flavonoids and Their Antioxidant activities in Maize Plants Treated with Zn (II) HEDTA Grown in Salinized Media . Agricultural Sciences. 2015; 6(3): 397405.

[45] Hichem H, Mounir D, Naceur EA. Differential responses of two maize (Zea mays L.) varieties to salt stress: Changes on polyphenols composition of foliage and oxidative damages, Industrial Crops Production. 2009; 30(1): 144151.

[46] Radi AA, Farghaly FA, Hamada AM. Physiological and biochemical responses of salt-tolerant and salt-sensitive wheat and bean cultivars to salinity. Journal of Biology and Earth Sciences. 2013; 3(1): B72-B88.

[47] Kapoor K, Srivastava A. Assessment of salinity tolerance of Vinga mungo var. Pu-19 using ex vitro and in vitro methods. Asian Journal of Biotechnology. 2010; 2(2): 73-85. 
[48] Cusido RM, Palazon J, Altobella T, Morales C. Effect of salinity on soluble protein, free amino acids and nicotine contents in Nicotiona rustica L. Plant Soil. 1987; 102(1): 55-60.

[49] Dhanapackiam S, Ilyas M. Effect of salinity on chlorophyll and carbohydrate contents of Sesbania grandiflora seedlings. Indian Journal of Science Technology. 2010; 3(1): 64-66.

[50] Shah AH, Shah SH, Ahmad H, Swati ZA. Cross tolerance mechanisms of osmotic and ionic stress adapted cell lines of rice towards salinity. International Journal of Agriculture and Biology. 2015; 17(5): 1019-1024. 